\title{
Regulation of Schwann Cell Morphology and Adhesion by Receptor-Mediated Lysophosphatidic Acid Signaling
}

\author{
Joshua A. Weiner, ${ }^{1,2}$ Nobuyuki Fukushima, ${ }^{1}$ James J. A. Contos, ${ }^{1,2}$ Steven S. Scherer, ${ }^{3}$ and Jerold Chun ${ }^{1,2}$ \\ ${ }^{1}$ Department of Pharmacology and ${ }^{2}$ Neurosciences Graduate Program, School of Medicine, University of California, San \\ Diego, La Jolla, California 92093, and ${ }^{3}$ Department of Neurology, University of Pennsylvania Medical Center, Philadelphia, \\ Pennsylvania 19104
}

In peripheral nerves, Schwann cells (SCs) form contacts with axons, other SCs, and extracellular matrix components that are critical for their migration, differentiation, and response to injury. Here, we report that lysophosphatidic acid (LPA), an extracellular signaling phospholipid, regulates the morphology and adhesion of cultured SCs. Treatment with LPA induces f-actin rearrangements resulting in a "wreath"-like structure, with actin loops bundled peripherally by short orthogonal filaments. The latter appear to anchor the SC to a laminin substrate, because they colocalize with the focal adhesion proteins, paxillin and vinculin. SCs also respond to LPA treatment by forming extensive cell-cell junctions containing $N$-cadherin, resulting in cell clustering. Pharmacological blocking experiments indicate that
LPA-induced actin rearrangements and focal adhesion assembly involve Rho pathway activation via a pertussis toxininsensitive G-protein. The transcript encoding $\mathrm{LP}_{\mathrm{A} 1}$, the canonical G-protein-coupled receptor for LPA, is upregulated after sciatic nerve transection, and SCs cultured from $I p_{A 1}$-null mice exhibit greatly diminished morphological responses to LPA. Cultured SCs can release an LPA-like factor implicating SCs as a potential source of endogenous, signaling LPA. These data, together with the previous demonstration of LPA-mediated SC survival, implicate endogenous receptor-mediated LPA signaling in the control of SC development and function.

Key words: LPA; N-cadherin; focal adhesion; actin; edg2; G-protein-coupled receptor
Schwann cells (SCs), the myelinating glia of the peripheral nervous system, are derived from the embryonic neural crest. SC precursors migrate into developing nerves, forming loose contacts with multiple axons. As SCs differentiate, they lose contact with all but a single axon segment, which they subsequently ensheathe with cytoplasmic processes or with a myelin internode (Zorick and Lemke, 1996). Axonal contacts with developing SCs are essential for myelination to proceed, with influences on the expression of myelin genes and assembly of the SC extracellular matrix (ECM) (Bunge et al., 1989; Scherer et al., 1994; Scherer, 1997). In addition, SC-axon and SC-SC interactions are essential for regeneration after nerve injury: SCs form elongated "bands of Bungner" that bridge the injury site and provide an adhesive substrate for regrowing axons (Cajal, 1928; Fu and Gordon, 1997).

Some of the molecules underlying these interactions have been identified. SCs produce basement membrane components including laminin, type IV collagen, entactin, and fibronectin, to which

\footnotetext{
Received April 10, 2001; revised May 29, 2001; accepted June 26, 2001.

This work was funded by grants from the National Institute of Mental Health (NIMH) (J.C.), National Research Service Award predoctoral fellowships from the NIMH (J.W., J.J.A.C.), and the Uehara Foundation (N.F.). We gratefully thank Drs. Kristjàn Jessen and David Parkinson (University College, London, UK) for the generous gift of embryonic mouse nerve cDNA. Y-27632 was the kind gift of Masayoshi Uehata (WelFide Corporation, Saitama, Japan). We thank Dr. Don Cleveland for critically reading this manuscript and Drs. Valerie Sah, Paul Martin, and Greg Lemke for helpful comments.

J.W. and N.F. contributed equally to this work.

Correspondence should be addressed to Jerold Chun at his present address: Merck Research Laboratories, San Diego, 3535 General Atomics Court, San Diego, CA 92121. E-mail: jerold_chun@merck.com.

J.A. Weiner's present address: Department of Anatomy and Neurobiology, Washington University School of Medicine, 660 South Euclid Avenue, St. Louis, MO 63110.

Copyright (ㄷ) 2001 Society for Neuroscience $\quad 0270-6474 / 01 / 217069-10 \$ 15.00 / 0$
}

they adhere via integrin receptors, dystroglycan and $N$-syndecan (Bunge et al., 1989; Mirsky and Jessen, 1996; Scherer, 1997). Interactions with ECM components such as laminin may be important for both SC migration (Milner et al., 1997) and myelination (Fernandez-Valle et al., 1994; Chen et al., 2000). The calcium-dependent, homophilic adhesion molecule $N$-cadherin is expressed by SCs in vivo (Cifuentez-Diaz et al., 1994). It is important for SC-axon and SC-SC interactions in vitro (Letourneau et al., 1991), and is present at sites of SC-axon contact during regeneration (Shibuya et al., 1995). In addition, actin cytoskeleton-based morphological rearrangements are critical for SC differentiation and myelination (Fernandez-Valle et al., 1997), and may be modulated both by integrins, through the assembly of focal adhesions (Fernandez-Valle et al., 1998; Longhurst and Jennings, 1998; Chen et al., 2000), and by $N$-cadherin, through its intracellular catenin signaling partners (Yap et al., 1997).

Comparatively less is known about the signaling pathways that regulate $\mathrm{SC}$ adhesion and morphology. One attractive candidate is the growth factor-like serum phospholipid lysophosphatidic acid (LPA). LPA signals through G-protein-coupled receptors (GPCRs) to induce diverse cellular effects, including actin rearrangements and focal adhesion assembly via the small GTPase, Rho, and its downstream effectors (Moolenaar et al., 1997; Fukushima et al., 1998; Chun et al., 1999). Recent studies have identified three genes encoding GPCRs for LPA: $l p_{A 1} / E d g 2, l p_{A 2} /$ $E d g 4$, and $l p_{A 3} / E d g 7$, which together encode the $\mathrm{LP}_{\mathrm{A}}$ receptor family (Hecht et al., 1996; Fukushima et al., 1998, 2001; Chun et al., 1999; Contos et al., 2000a). We demonstrated previously that $l p_{A 1}$ is expressed by postnatal SCs in vivo and in vitro and that LPA promotes SC survival via activation of $\mathrm{LP}_{\mathrm{A} 1}$ and a downstream pathway including $\mathrm{G}_{\mathrm{i}}$, phosphoinositide-3-kinase (PI3K), and Akt (Weiner and Chun, 1999). Here, we examine the cy- 
toskeletal and ECM effects of $\mathrm{LP}_{\mathrm{A} 1}$-mediated LPA signaling in primary SCs cultures, including cells derived from mice lacking $l p_{A 1}$, and assess possible sources of endogenous LPA.

\section{MATERIALS AND METHODS}

Reagents and pharmacological treatments. Lyophilized LPA (Avanti Polar Lipids) was resuspended and diluted in $\mathrm{H}_{2} \mathrm{O}$. Lysophosphatidyl choline, lysophosphatidyl ethanolamine, lysophosphatidyl glycerol, and phosphatidic acid (all from Avanti Polar Lipids) were resuspended in $\mathrm{H}_{2} \mathrm{O}$. Sphingosine 1-phosphate (S1P) (Biomol, Plymouth Meeting, PA) was prepared in $0.01 \%$ fatty acid-free BSA. C3 exoenzyme was prepared, and its efficacy was confirmed, as described (Fukushima et al., 1998). Cultures were treated with $30 \mu \mathrm{g} / \mathrm{ml} \mathrm{C} 3$ for $\sim 18 \mathrm{hr}$ before LPA treatment. Y-27632 was added to cultures at $2 \mu \mathrm{M} 10 \mathrm{~min}$ before LPA treatment. Pertussis toxin (PTX; Calbiochem, La Jolla, CA) was added at $200 \mathrm{ng} / \mathrm{ml}$ to cultures $\sim 18 \mathrm{hr}$ before, and again at the time of, LPA treatment. Efficacy of PTX was confirmed in an in vitro ADP-ribosylation assay using SC membranes (data not shown).

Primary SC culture. Sciatic nerves were excised from rats at postnatal day 2 or 3 or from wild-type or $l p_{A 1}{ }^{(-)-)}$mice (Contos et al., 2000b) at postnatal day 3 or 4 , and SCs were purified essentially as described previously (Brockes et al., 1979). Cells were passaged routinely on poly-L-lysine $(0.1 \mathrm{mg} / \mathrm{ml})$-coated dishes and plated for experiments on poly-L-lysine and laminin $(10 \mu \mathrm{g} / \mathrm{ml})$-coated glass coverslips. Growth medium was DMEM (Life Technologies, Gaithersburg, MD) supplemented with $10 \% \mathrm{FCS}, 20 \mu \mathrm{g} / \mathrm{ml}$ pituitary extract (Sigma), $2 \mu \mathrm{M}$ forskolin, and penicillin-streptomycin. For serum-free experimental conditions, a modified "Sato" medium (Milner et al., 1997) was used, consisting of DMEM with $1 \times$ N2 supplements (Life Technologies), 20 $\mu \mathrm{g} / \mathrm{ml}$ pituitary extract, $0.1 \mathrm{mg} / \mathrm{ml}$ fatty acid-free BSA (Sigma), $400 \mathrm{ng} / \mathrm{ml}$ each of T3 and T4 (Sigma), $4 \mu \mathrm{M}$ forskolin, and penicillin-streptomycin. In experiments in which $\mathrm{Ca}^{2+}$ concentration was manipulated, Sato medium was prepared using $\mathrm{CaCl}_{2}$-free DMEM (Life Technologies), and $\mathrm{CaCl}_{2}$ was then added to 0.2 or $2 \mathrm{~mm}$. Cultures were serum-starved in Sato medium overnight (12-18 hr) before LPA treatments. SC cultures were $>98 \%$ pure, as assessed by anti- $\mathrm{P}_{0}$ and anti-S100 (Dako, Carpinteria, CA) immunofluorescence. For conditioned medium (CM) production, near-confluent SC cultures were maintained in Sato medium for 72 hr. CM was collected, filtered $(0.2 \mu \mathrm{m})$, and applied to assay cultures immediately. In some cases, early passage SCs were cryoprotected in DMEM with $20 \%$ FCS and $10 \%$ DMSO and stored in vials under liquid $\mathrm{N}_{2}$. Once thawed, SCs were used for no more than three passages before being discarded, and maintenance of cellular phenotype was routinely monitored by immunofluorescence.

Immunofluorescence and actin staining. SC cultures were fixed for 15 min with $4 \%$ paraformaldehyde and rinsed several times with PBS. Coverslips were incubated in blocking solution containing $2 \%$ BSA and $0.1 \%$ Triton X-100 in PBS for $1 \mathrm{hr}$, followed by overnight incubation with the following monoclonal antibodies (all from Transduction Laboratories, Lexington, $\mathrm{KY})$ : anti-vinculin $(5 \mu \mathrm{g} / \mathrm{ml})$, anti-paxillin $(0.5 \mu \mathrm{g} / \mathrm{ml})$, anti- $N$-cadherin $(5 \mu \mathrm{g} / \mathrm{ml})$, and anti- $\beta$-catenin $(1.5 \mu \mathrm{g} / \mathrm{ml})$. Bound antibodies were visualized with biotinylated anti-mouse IgG (Vector Laboratories, Burlingame, CA; 1:200), followed by Alexa488-streptavidin (Molecular Probes, Eugene, OR; $2 \mu \mathrm{g} / \mathrm{ml}$ ). For visualization of f-actin, cells were incubated with TRITC-phalloidin $(0.1 \mu \mathrm{g} / \mathrm{ml})$. Nuclei were counterstained with 4',6'-diamidino-2-phenylindole (DAPI) (Sigma, St. Louis, MO; $10 \mathrm{~min}$ at $0.35 \mu \mathrm{g} / \mathrm{ml}$ ).

Reverse transcription-PCR. Reverse transcription-PCR (RT-PCR) was performed as described previously (Contos and Chun, 1998). cDNAs were prepared from mouse sciatic nerve at embryonic day 12.5 (E12.5), E13.5, E15.5, and E17.5 (a kind gift from Drs. David Parkinson and Kristjàn Jessen, University College, London, UK) or from cultured SCs or neonatal sciatic nerves of $l p_{A I}^{(+)+)}$and $l p_{A I}{ }^{(-)}$mice, using standard protocols. Primers used for PCR were the following: $l p_{A 1}: 513 \mathrm{C} / 513 \mathrm{~T}$; $l p_{A 2}$ : edg6f/edg6e $3 \mathrm{c}^{\prime}$ (Contos and Chun, 2000); $l p_{B 1}$ : edg1p (5'-CCGTCAGTCGCCGACAACAA-3')/edg1b (5'-GTAGAGGATGGCGATGGAAA-3'); $l p_{B 2}$ : edg4SP12 (5'-AGC CAA CAG TCT CCA AAA CCA$\left.3^{\prime}\right) /$ edg4b (5'-ACG ATG GTG ACC GTC TTG AGC A-3'); $l p_{B 3}$ : edg3SP6 (5'-AGG GGC AGG CGA CAA GGT-3')/edg3c (5'-GGG TTC ATG GCG GAG TTG AG-3'). To prevent any potential contaminating signal from genomic DNA, all primer pairs were designed so that the amplified product would cross an intron-exon boundary. Control reactions using genomic DNA as a template were negative in all cases (see Fig. $6 f$ ). Southern blot analysis for PCR products was performed using standard protocols (Ausubel et al., 1994) with a ${ }^{32} \mathrm{P}-$ labeled fragment of the $l p_{A 1}$ open reading frame probe.

Northern blot of transected sciatic nerve RNA. Adult rat sciatic nerve transections were performed essentially as described previously (Scherer et al., 1994). Briefly, the sciatic nerve was exposed at the sciatic notch. The nerve was double ligated and transected with fine scissors, and the two nerve stumps were sutured at least $1 \mathrm{~cm}$ apart; this technique prevents axonal regeneration to the distal nerve stump for at least 2 months. At various times after transection, the animals were killed, the entire distal nerve stumps (from just below the lesion to the ankle) were removed, and RNA extracted by standard methods (Ausubel et al., 1994). Northern blots of $10 \mu \mathrm{g}$ each RNA were made and probed with the following ${ }^{32} \mathrm{P}$-labeled $\left(1 \times 10^{6} \mathrm{cpm} / \mathrm{ml}\right)$ cDNA fragments: a full-length $l p_{\mathrm{A} 1}$ cDNA insert (Hecht et al., 1996); a $0.7 \mathrm{~kb}$ Bam HI fragment of p75 (the low-affinity nerve growth factor receptor; Radeke et al., 1987); a full-length cDNA of rat $\mathrm{P}_{0}$ (Lemke and Axel, 1985); and a full-length cDNA of rat glyceraldehyde 3-phosphate dehydrogenase (GAPDH; Fort et al., 1985).

Determination of LPA-like activity in SC CM. LPA-like activity was assayed by measuring stress fiber-forming activity in RH7777 cells expressing $l p_{\mathrm{A} 1}\left(\mathrm{RH} / \mathrm{LP}_{\mathrm{A} 1}\right.$ cells), and S1P-like activity was assayed by measuring cell rounding activity in B103 neuroblastoma cells (Fukushima et al., 1998). Native RH7777 cells (which express no known LPA receptors and exhibit no LPA responsivity) were infected with retroviruses expressing FLAG-tagged $l p_{A I}$ for $18 \mathrm{hr}$ and further cultured in 300 $\mu \mathrm{l}$ of serum-free medium for $1 \mathrm{~d}$. SC-CM was added for $30 \mathrm{~min}$, and cells were fixed and double-stained for FLAG and f-actin (Fukushima et al., 1998, 2000). FLAG-positive cells with stress fibers were counted, and the concentration of LPA-like activity in CM was estimated by comparison to a standard LPA dose-response curve $(0.3-10 \mathrm{nM})$. B103 cells were serum-starved overnight and treated with SC-CM for $30 \mathrm{~min}$. Cells were fixed and rounded cells were counted under phase-contrast optics.

Figure preparation. Micrographs and gel photographs were scanned into Adobe Photoshop 4.0, which was used to compile the composite figures, to equalize brightness, contrast, and color balance, and to add text.

\section{RESULTS}

\section{LPA induces actin cytoskeleton-based morphological changes in cultured SCs}

During previous studies of the effects of LPA on SC survival (Weiner and Chun, 1999), we noted that LPA treatment appeared to produce concomitant changes in cell morphology. This effect was examined further in cultured neonatal rat SCs. Control SCs grown on laminin in a defined, serum-free medium exhibited a stereotypical bipolar morphology with elongated processes (Fig. 1a), whereas SCs treated with LPA lost their processes and adopted a flattened morphology accompanied by cell spreading (Fig. 1b). Because LPA is known to be a potent effector of actin cytoskeletal rearrangements in numerous cell types (Jalink et al., 1993; Moolenaar et al., 1997; Fukushima et al., 1998), we examined SCs for changes in actin structure after LPA treatment.

In control SC cultures, f-actin visualized with TRITC-phalloidin was organized into several bright bundles oriented along the cell axis (Fig. 1c). SCs treated with LPA (1 $\mu \mathrm{M}, 3 \mathrm{hr}$ ) exhibited a dramatic reorganization of the cytoskeleton, forming compact, circular bundles of actin filaments resembling a wreath (Fig. 1d). At higher magnification, this actin structure could be seen to consist of fine loops of f-actin, apparently interconnected by several short, orthogonal actin filaments that extended centripetally toward other SCs or the laminin substrate (Fig. 1e). The reorganized actin was neither strictly cortical nor perikaryal, because it was excluded from areas directly abutting the nucleus and plasma membrane (see Fig. $4 g$ ).

LPA induction of actin rearrangements was dose-dependent and was maximal at $1 \mu \mathrm{M}$, with an estimated $\mathrm{EC}_{50}$ of $50 \mathrm{~nm}$ (Fig. $1 f)$. Although complete wreath formation was useful as an unambiguous criterion for quantitation, this tended to underesti- 


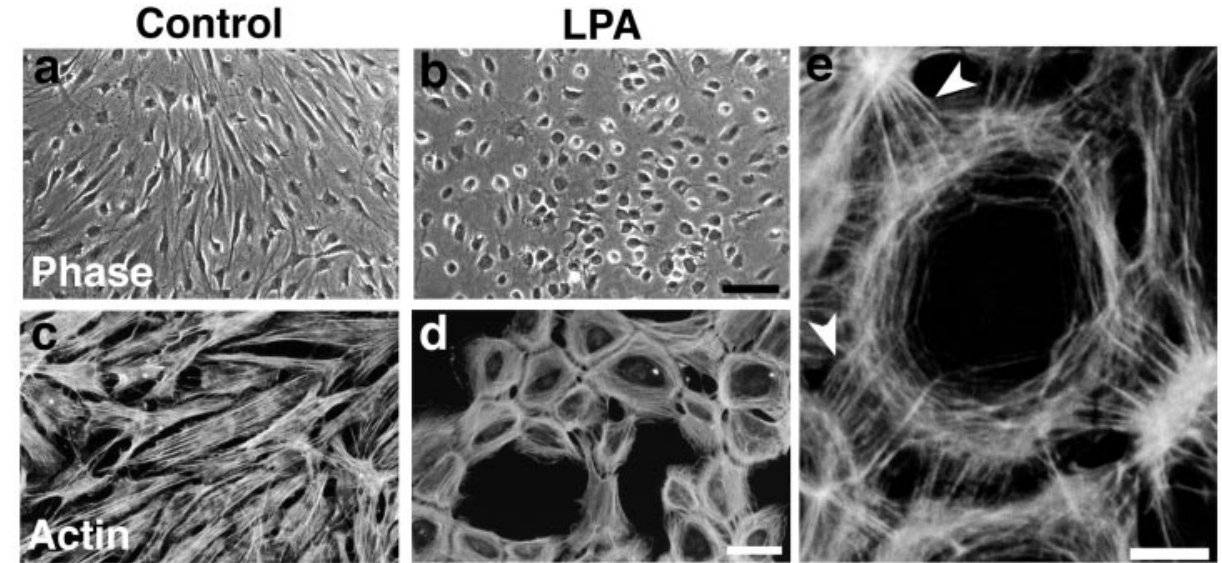

f

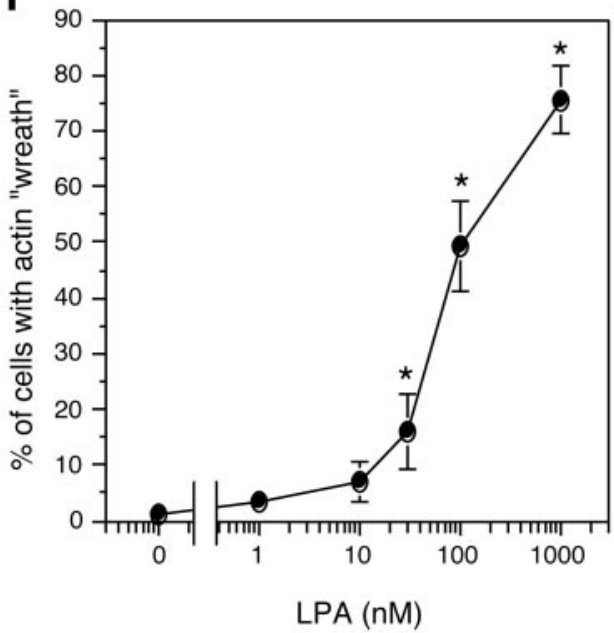

g

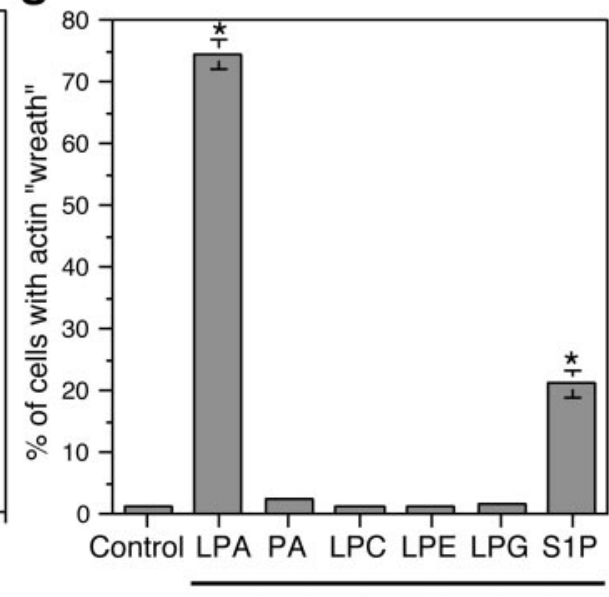

$1 \mu \mathrm{M}$
Figure 1. LPA induces marked, actin cytoskeleton-based morphological changes in Schwann cells. $a-d$, Phase contrast microscopy $(a, b)$ and TRITC-phalloidin-stained f-actin images $(c, d)$ of control and LPA-treated SCs. $\mathrm{SCs}$ in control cultures $(a, c)$ exhibit bipolar morphologies with elongated processes containing a small number of thick actin bundles. Treatment with $1 \mu \mathrm{M}$ LPA (3 hr) results in process retraction, cell flattening, and spreading, and the formation of a polymerized actin wreath-like structure $(b, d)$. Scale bars: $a, b, 100$ $\mu \mathrm{m} ; c, d, 50 \mu \mathrm{m} . e$, Higher magnification view of an LPA-treated SC stained with TRITCphalloidin. The actin wreath can be seen to consist of many loops of f-actin apparently bundled by short orthogonal filaments (arrowheads). Scale bar, $10 \mu \mathrm{m}$. $f$, Dose-response relationship of LPA-induced actin wreath formation. ${ }^{*} p<0.003$ (vs control; ANOVA with Fisher's post hoc test). Values represent means $\pm \operatorname{SEM}(n=6) . g$, The effects of various lysophospholipids on actin wreath formation. $P A$, Phosphatidic acid; $L P C$, lysophosphatidyl choline; $L P E$, lysophosphatidyl ethanolamine; $L P G$, lysophosphatidyl glycerol; $S 1 P$, sphingosine 1-phosphate. ${ }^{*} p<0.0001$ (vs control; ANOVA with Fisher's post hoc test). Values represent means $\pm \operatorname{SEM}(n=6)$. mate the potency of LPA because low nanomolar doses induced substantial, but incomplete, actin rearrangements in most SCs (data not shown). Similarly, all SCs responded to $1 \mu \mathrm{M}$ LPA with profound actin rearrangements, although only 75-80\% assembled a clearly complete actin wreath (Fig. 1f). The response was specific for LPA, because the structurally related lipids, phosphatidic acid, lysophosphatidyl choline, lysophosphatidyl ethanolamine, and lysophosphatidyl glycerol failed to induce any actin rearrangements (Fig. 1g). Another type of lysophospholipid, S1P, which also induces cytoskeletal effects via cognate GPCRs homologous to the $\mathrm{LP}_{\mathrm{A}}$ family (the $\mathrm{LP}_{\mathrm{B}}$ receptor family; Postma et al., 1996; Lee et al., 1998; Chun et al., 1999; van Brocklyn et al., 1999; Zhang et al., 1999; Fukushima et al., 2001), did produce significant actin reorganization, but with much less efficacy than LPA in this assay (Fig. $1 g$ ).

To examine how these actin rearrangements progressed over time, SCs were exposed to LPA, fixed, and stained with TRITCphalloidin at various time points. As early as 15 min after LPA exposure, all SCs examined exhibited the onset of actin reorganization, accompanied by changes in cell shape (Fig. 2, compare $a, b)$. Fine actin filaments appeared to bundle and thicken with time, with the subsequent formation of orthogonal actin filaments (Fig. $2 c-e)$. Although maximal actin wreath formation was observed 1-3 hr after LPA exposure (Fig. 2f), some SCs had completed actin reorganization by $15-30 \mathrm{~min}$ (Fig. $2 b$, arrowhead).

Extracellular LPA activates multiple G-protein signaling path- ways, including a PTX-sensitive $\mathrm{G}_{\mathrm{i}} / \mathrm{PI} 3 \mathrm{~K}$ pathway important for SC survival (Weiner and Chun, 1999) and a PTX-insensitive Rho pathway leading to cytoskeletal rearrangements in many cell types (Moolenaar et al., 1997; Fukushima et al., 1998; Gohla et al., 1998). Consistent with this, SC actin rearrangements were blocked completely both by C3 exoenzyme, which ADPribosylates and inactivates Rho (Jalink et al., 1994), and by Y-27632, a specific inhibitor of p160ROCK, an effector kinase downstream of Rho (Uehata et al., 1997) (Fig. $2 g$ ). In contrast, PTX treatment did not inhibit LPA-induced actin rearrangements (Fig. 2g).

\section{LPA induces SC focal adhesion assembly}

SC function depends critically on adhesive interactions with ECM components such as laminin (Bunge et al., 1989), which are mediated in part by the focal adhesion complexes that link integrins to the actin cytoskeleton (Fernandez-Valle et al., 1994, 1998; Milner et al., 1997; Chen et al., 2000). To determine whether LPA-induced actin rearrangement was accompanied by focal adhesion assembly, SCs were treated with LPA and subsequently double stained with TRITC-phalloidin and antibodies against paxillin or vinculin, two protein components of focal adhesion complexes (Longhurst and Jennings, 1998). Control SCs had relatively few paxillin- or vinculin-positive focal adhesions where they contacted the laminin substrate (Fig. 3a-c). After LPA treatment, SCs exhibited many bright paxillin- and vinculin-positive focal adhesions at the outer edge of the actin 

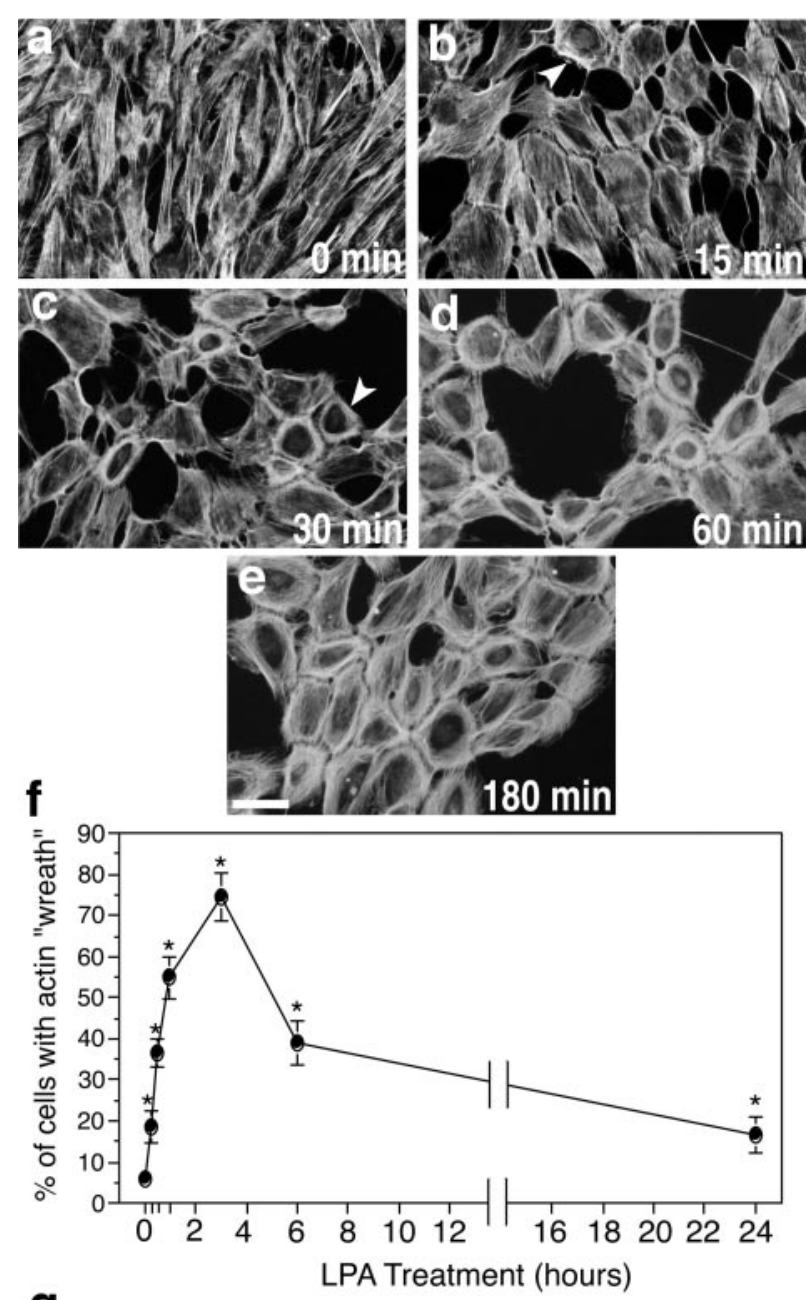

g

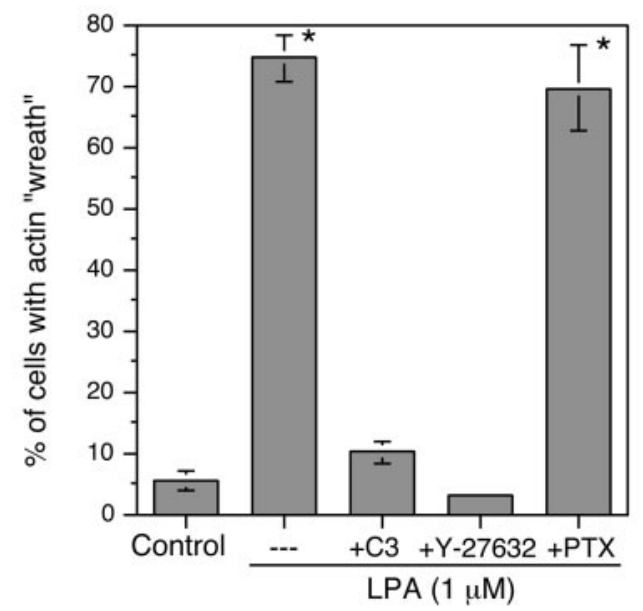

Figure 2. LPA-induced actin rearrangements in Schwann cells are initiated rapidly and depend on Rho activation. $a-e$, TRITC-phalloidin staining of SCs treated with $1 \mu \mathrm{M}$ LPA for the indicated times. $f$, Quantitated time course of LPA-induced actin wreath formation. Actin rearrangement is initiated rapidly, with some SCs already exhibiting mature wreath structures by $15-30 \mathrm{~min}$ (arrowheads in $b, c$ ), and is half-maximal by $30 \mathrm{~min}(f)$. Wreath formation is maximal between 1 and $3 \mathrm{hr}$, after which the structures are gradually lost. $g$, Quantitation of the effects of pharmacological inhibitors on LPA-induced actin wreath formation. LPA-induced actin reorganization is completely blocked by pretreatment with C3 exoenzyme $(30 \mu \mathrm{g} / \mathrm{ml}, 18 \mathrm{hr})$ or with Y-27632 $(2 \mu \mathrm{M}$, $10 \mathrm{~min})$, but not with PTX $(200 \mathrm{ng} / \mathrm{ml}, 18 \mathrm{hr})$. Scale bar, $50 \mu \mathrm{m} .{ }^{*} p<$ 0.0005 (vs control; ANOVA with Fisher's post hoc test). Values represent means $\pm \operatorname{SEM}(n=6)$. structure, where they contacted the substrate (Fig. $3 d-f, i$ ). Merged images (Fig. 3f,i) illustrated colocalization of f-actin with focal adhesion proteins near the cell surface. LPA-induced assembly of focal adhesions was blocked by pretreatment with Y-27632 (Fig. 3g,h) but not by PTX (data not shown), indicating involvement of the Rho/ROCK pathway, consistent with previous reports (Ridley and Hall, 1992; Uehata et al., 1997). Focal adhesion assembly was observed as early as $15 \mathrm{~min}$ after LPA exposure (Fig. $3 g$ ), although maximal effects were seen at 1-3 hr, concomitantly with the completion of actin reorganization. Both LPAinduced actin rearrangements and focal adhesion assembly were weak or nonexistent when SCs were grown on a substrate of poly-L-lysine alone (data not shown). These data, taken together, suggest that LPA signaling can increase SC adhesion to ECM components through focal adhesion complex assembly.

\section{LPA induces $\mathbf{N}$-cadherin-mediated cell-cell contacts in SCs}

Compared with control cells, LPA-treated SCs appeared to cluster together as they assembled actin wreath structures (Fig. 2a-e). Because SC-SC and SC-neurite contacts have been shown to depend on the homophilic calcium-dependent cell adhesion molecule $N$-cadherin (Letourneau et al., 1990, 1991; Shibuya et al., 1995), we examined whether LPA increased $N$-cadherinmediated cell contacts. Control and LPA-treated cultures were double stained with TRITC-phalloidin and an antibody against $N$-cadherin. SCs in control cultures exhibited few $N$-cadherinpositive contacts, and these generally covered a small area (Fig. $4 a-c)$. In LPA-treated cultures, SCs with actin wreaths appeared closely linked to one another, with large, bright $N$-cadherinpositive junctions that spanned the entire cell-cell border (Fig. $4 d-f)$. A similar pattern was also obtained using an antibody against $\beta$-catenin, an intracellular signaling molecule associated with $N$-cadherin (Fig. $4 g$ ).

Growing SCs in medium containing a low concentration $(0.2$ $\mathrm{mm}$ ) of $\mathrm{CaCl}_{2}$, demonstrated previously to disrupt calciumdependent cadherin binding (Letourneau et al., 1991), did not affect LPA-induced actin rearrangements (Fig. 4, compare $h, j$ ). Cell-cell adhesion, however, was significantly disrupted, resulting in single, dissociated wreath-containing SCs that completely lacked $N$-cadherin-positive contacts (Fig. 4, compare $i, k$ ). These results confirmed that LPA-induced cell-cell contacts were cadherin-based and further demonstrated that these contacts were not simply a consequence of actin reorganization.

\section{The $L P_{A 1}$ receptor gene is expressed throughout sciatic nerve development and is upregulated after injury}

Aspects of SC morphology and adhesion modulated by LPA in vitro have been suggested to be important for migration, myelination, and response to nerve injury in vivo (Bunge et al., 1989; Letourneau et al., 1991; Fernandez-Valle et al., 1994, 1997, 1998; Fu and Gordon, 1997; Milner et al., 1997). To determine whether LPA could regulate such processes in vivo, we examined the expression of $l p_{A 1}$, the major LPA receptor gene in the postnatal nerve (Weiner and Chun, 1999), during embryonic nerve development and after adult nerve transection. First, we performed RT-PCR with primers specific for the $l p_{A 1}$ gene on cDNAs derived from embryonic and neonatal mouse sciatic nerves. The $l p_{A 1}$ transcript was detected at all ages examined, including the period ( $\sim$ E12-E15) when SC precursors migrate along the developing nerve (Fig. 5a) (Jessen et al., 1994; Mirsky and Jessen, 1996; Scherer, 1997). The fragment amplified by RT-PCR was 

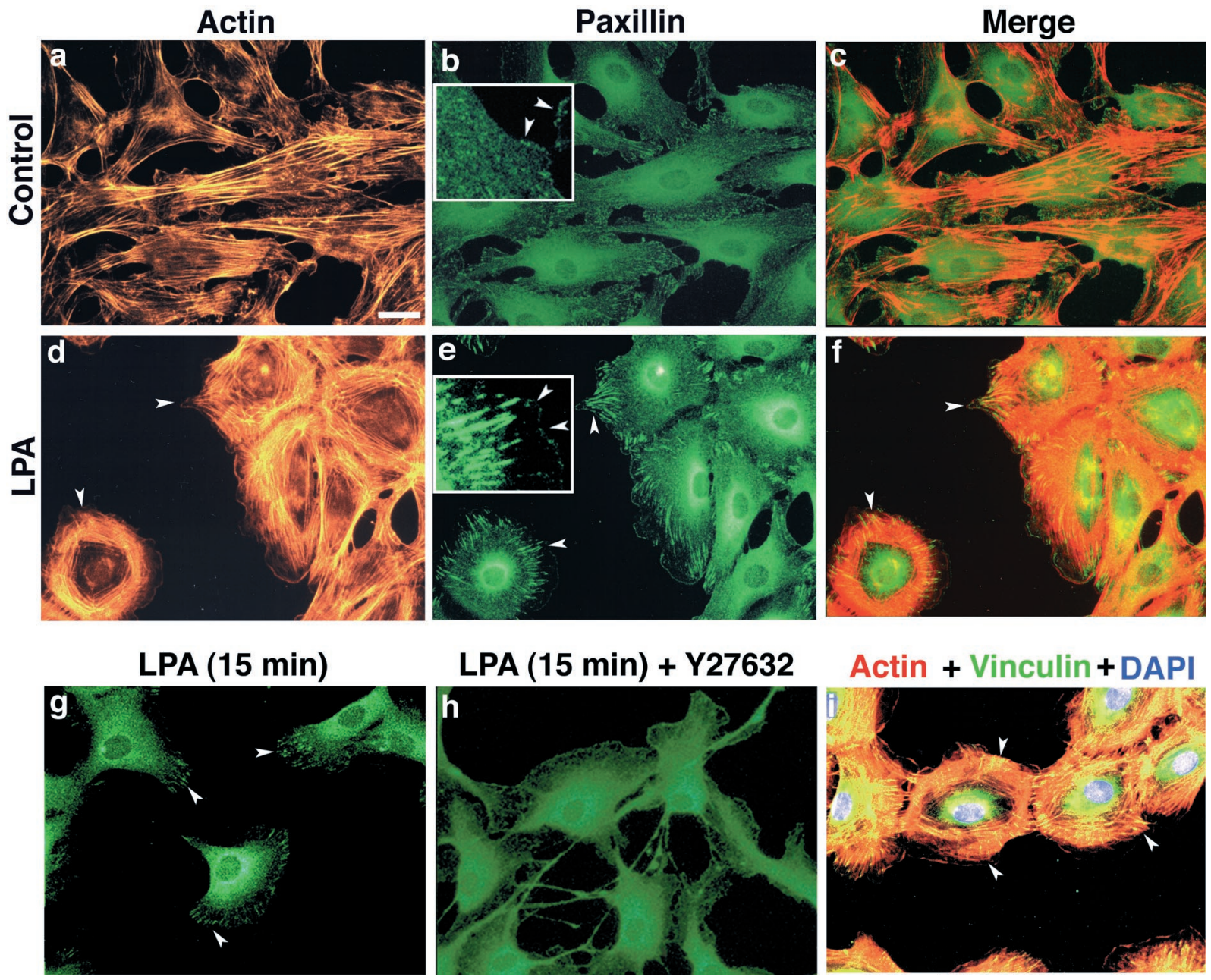

Figure 3. LPA induces focal adhesion assembly in Schwann cells. $a-f$, Control and LPA-treated SCs stained with TRITC-phalloidin (red) and an antibody to the focal adhesion protein paxillin ( green). Control SCs have relatively few focal adhesions. In contrast, LPA-treated SCs have many bright paxillin-positive (e) or vinculin-positive ( $i)$ "spikes" near the cell periphery (arrowheads), indicating increased focal adhesion assembly. Insets in $b$ and $e$ are $3 \times$ magnifications of a portion of the field showing the cell periphery, with the plasma membrane indicated with arrowheads. Merged or triple-exposure images (including nuclei stained with DAPI; blue) indicate the expected colocalization of actin with focal adhesion proteins (seen as yellow). $g$, $h$, Effect of Y-27632 on LPA-induced focal adhesion assembly. When SCs were treated with Y-27632 before 15 min LPA treatment, focal adhesion assembly was blocked. Although the maximal effect was seen in longer LPA treatments $(e)$, note that initial focal adhesion assembly was observed as early as $15 \mathrm{~min}$ after LPA exposure $(g)$. Scale bar, $25 \mu \mathrm{m}$.

confirmed to represent $l p_{A 1}$ by Southern blot analysis using an $l p_{A 1}$ probe devoid of employed primer sequence (Fig. $5 a$ ). We next analyzed, by Northern blot, $l p_{A 1}$ expression in the distal nerve stumps of adult rat sciatic nerves after transection. SCs modify their gene expression after transection, downregulating genes indicative of mature, myelinating phenotype $\left(\mathrm{P}_{0}\right)$ while upregulating genes indicative of an immature, regenerationsupporting phenotype (GAP43 and the p75 nerve growth factor receptor) (Fig. 5b) (Fu and Gordon, 1997; Scherer, 1997). Expression of the $l p_{A 1}$ transcript increased in distal nerve stumps $\sim 1$ week after transection, and this increase was maintained for at least 8 weeks, similar to that of GAP-43 (Fig. 5b). This time course further parallels the upregulation of ECM components and cell adhesion molecules, including $N$-cadherin, which has been reported previously (Bunge et al., 1989; Cifuentez-Diaz et al., 1994; Fu and Gordon, 1997).

\section{LPA-induced actin rearrangement is decreased in SCs lacking $/ p_{\mathrm{A} 1}$ expression}

$\mathrm{LP}_{\mathrm{A} 1}$ is the major LPA receptor in the postnatal mouse sciatic nerve (Weiner and Chun, 1999), and therefore the role of this receptor in the morphological effects demonstrated here was examined. Neonatal SC cultures were prepared from wild-type $\left(l p_{A 1}{ }^{(+/)}\right)$mice and from mice $\left(l p_{A 1}{ }^{(-/-)}\right)$in which the gene encoding $\mathrm{LP}_{\mathrm{A} 1}$ was disrupted, resulting in a null genotype (Contos et al., 2000b). Approximately $50 \%$ of $l p_{A 1}{ }^{(-/)}$mice die between the perinatal period and weaning; thus, examined nerves were by necessity biased toward animals that could survive to 3-4 $\mathrm{d}$ postnatal, at which time nerves were isolated. Wild-type mouse SCs responded to LPA with dose-dependent actin rearrangements similar to those observed in rat SCs (Fig. 6a,c), albeit with a somewhat reduced maximal effect (Fig. 6e). In contrast, SCs cultured from $l p_{A 1}{ }^{(-)}$mice exhibited a severe reduction in the LPA response, with most cells failing to respond at all (Fig. $6 b, d, e)$. SCs from $l p_{A 1}{ }^{(+/+)}$and $l p_{A 1}{ }^{(-/-)}$mice responded equally well to S1P exposure (Fig. 6e) (note that the S1P response is stronger in mouse SCs than in rat SCs), indicating that the reduced effect did not result from a general cytoskeletal defect. Furthermore, these results demonstrate that $\mathrm{LP}_{\mathrm{A} 1}$ is not required for S1P-dependent responses. RT-PCR analyses (Fig. $6 f$ ) confirmed that $l p_{A 1}{ }^{(-)}$nerves and SC cultures lacked $l p_{A 1}$ expres- 

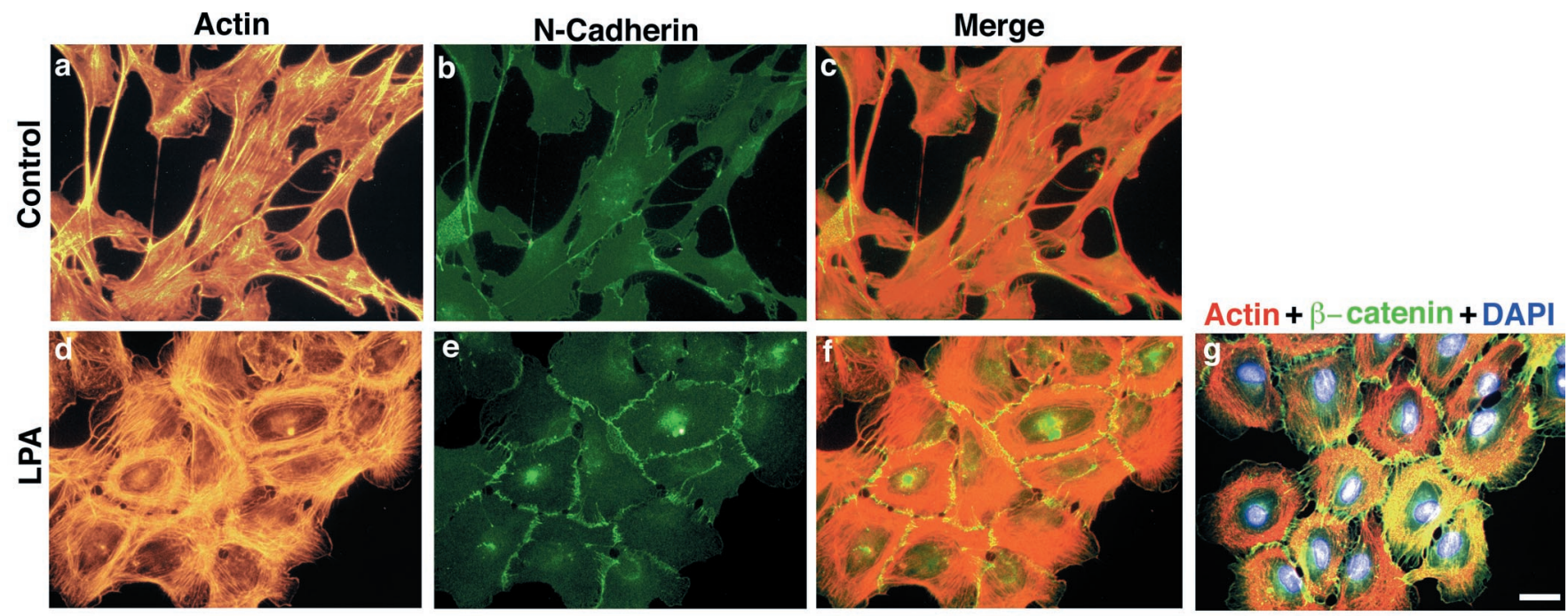

Low Ca2+

Normal Ca2+
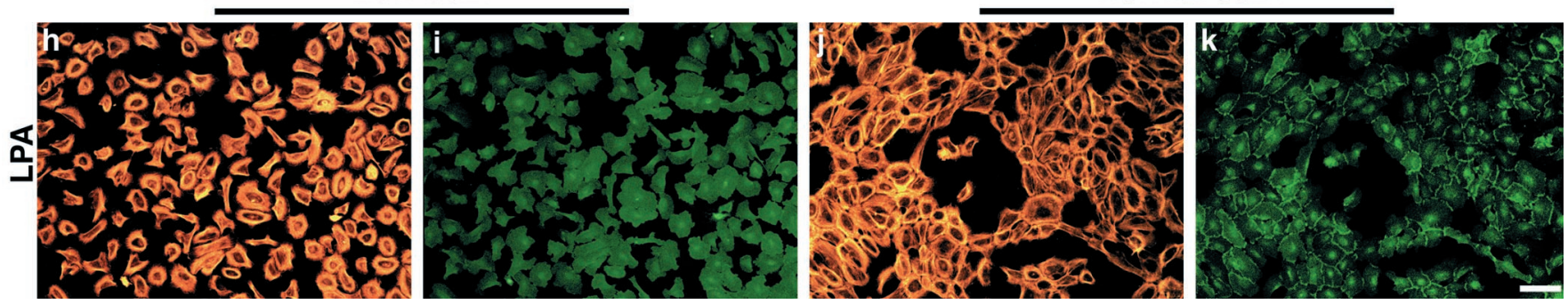

Figure 4. LPA induces $N$-cadherin-based cell-cell adhesion in cultured Schwann cells. $a-f$, Control and LPA-treated SCs stained with TRITCphalloidin (red) and an antibody to $N$-cadherin (green). , Triple staining of LPA-treated SCs with TRITC-phalloidin (red), an antibody to $\beta$-catenin (green), and the nuclear stain DAPI (blue). Control SCs have few bright $N$-cadherin-positive contacts. In contrast, LPA-treated SCs have many bright $N$-cadherin- or $\beta$-catenin-positive contacts that cover the entire cell-cell surface. Merged or triple-exposure images indicate the expected colocalization of $N$-cadherin and $\beta$-catenin with actin, to which the catenin complex binds. $h-k$, The effects of low $\mathrm{Ca}^{2+}$ concentration on LPA-induced actin wreath formation and $N$-cadherin-based clustering. SCs were treated with LPA $(1 \mu \mathrm{M}, 3 \mathrm{hr})$ in normal medium $(j, k)$ or in low $(0.2 \mathrm{~mm})$ calcium medium $(h$, i) known to disrupt calcium-dependent cadherin binding (Letourneau et al., 1991). Low calcium did not prevent LPA-induced wreath formation $(h)$ but did disrupt $N$-cadherin-mediated contacts $(i)$, resulting in single, dissociated wreath-containing SCs. Scale bars: $a, g, 25 \mu \mathrm{m} ; h-k, 100 \mu \mathrm{m}$.

sion, but continued expression of another LPA receptor gene, $l p_{A 2}$ (which may account for the residual LPA response), as well as multiple members of the $l p_{B} \mathrm{~S} 1 \mathrm{P}$ receptor gene family.

\section{SCs can release signaling LPA}

Actin wreaths in untreated SC cultures, essentially absent under the conditions of this study, could be produced by overgrowth of SCs (data not shown). This result suggested the possibility that SCs themselves might be capable of producing signaling LPA. To address this issue, culture medium conditioned for $72 \mathrm{hr}$ by confluent rat SCs was added to fresh SC cultures and assayed for actin reorganizing activity. Undiluted SC-CM, but not control medium, had an activity comparable with $30 \mathrm{~nm}$ LPA in this assay (Fig. 7a). To confirm that this activity was in fact LPA, we tested Schwann cell-conditioned medium ( $\mathrm{SC}-\mathrm{CM}$ ) in two sensitive and specific bioassays using cell lines expressing different complements of LP GPCRs (Fukushima et al., 1998, 2000): (1) RH7777 hepatoma cells, which normally lack any $l p_{A}$ or $l p_{B}$ receptor gene expression and thus respond to neither LPA nor S1P (Zhang et al., 1999), infected with a retrovirus encoding $\mathrm{LP}_{\mathrm{A} 1}$. These $\mathrm{RH} /$ $\mathrm{LP}_{\mathrm{A} 1}$ cells respond specifically to nanomolar LPA by forming stress fibers (Fukushima et al., 1998); and (2) B103 neuroblastoma cells, which lack any LPA receptors and responses, but express S1P receptors and respond specifically to S1P with neurite retraction and cell rounding (Fukushima et al., 1998; Chun et al.,
1999; Ishii et al., 2000). Application of SC-CM resulted in significant stress fiber formation in $\mathrm{RH} / \mathrm{LP}_{\mathrm{A} 1}$ cells (Fig. $7 b$ ), but had no effect on neurite retraction in B103 cells (indicating that no significant S1P-like activity was present) (Fig. 7c). When normalized to cellular protein from conditioning cultures, the specific LPA-like activity present in SC-CM was $\sim 0.99 \pm 0.35 \mathrm{nmol} / \mathrm{mg}$. Together, these analyses demonstrated that SCs can release active signaling LPA, providing at least one potential source in the developing nerve.

\section{DISCUSSION}

SC development depends critically on the regulation of adhesion both to ECM components of the basal lamina (Bunge et al., 1989; Scherer, 1997) and to axons and other SCs (Letourneau et al., 1990, 1991; Lemke, 1993; Cifuentez-Diaz et al., 1994; Scherer et al., 1994). SCs undergo changes in morphology and adhesion as they migrate, differentiate, and form the mature axonal contacts that lead to elaboration of the myelin sheath. Modulations of morphology and adhesion are similarly important after nerve injury, when SCs and their basal lamina- and cell adhesionassociated molecules form an adhesive substrate that promotes nerve regeneration (Shibuya et al., 1995; Fu and Gordon, 1997; Scherer, 1997). Several factors with the potential to affect SC adhesion have been identified. For example, NGF upregulates 
a

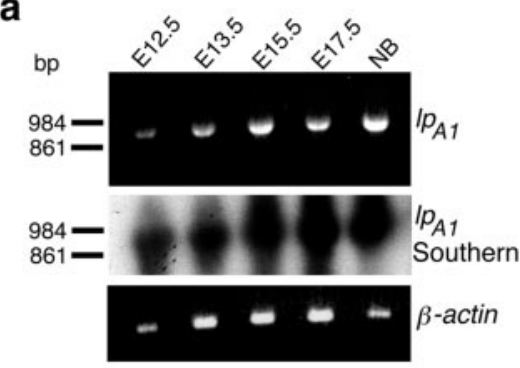

b

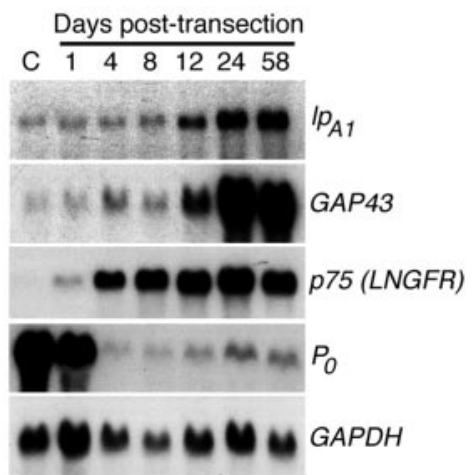

Figure 5. The $l p_{A 1}$ transcript is expressed in the embryonic sciatic nerve and is upregulated after adult sciatic nerve transection. $a$, RT-PCR analysis of embryonic (E12.5-E17.5) and newborn $(N B)$ mouse sciatic nerve cDNA using a primer pair crossing an intron-exon boundary (intron $>20 \mathrm{~kb}$ ). The $l p_{A 1}$ transcript is detected at all ages examined, including those (E12.5-E15.5) encompassing the period of SC migration (top panel). PCR of genomic DNA with the same primers gave no product (data not shown). A Southern blot of the PCR gel probed with a $l p_{A I}$ fragment confirms the identity of the product (middle panel). A $\beta$-actin PCR (bottom panel) is shown as a loading control. $b$, Northern blot analysis of RNA derived from adult rat sciatic nerves before ( $C$, control), and at subsequent days after transection (RNA is from the distal stumps). The $l p_{A 1}$ transcript is upregulated $\sim 1$ week after transection, and levels remain elevated for at least 8 weeks. This parallels similar rises in expression of markers of immature SCs, GAP43, and the p75 low-affinity nerve growth factor receptor ( $L N G F R)$, and contrasts with the abrupt downregulation of the gene encoding the myelin protein $\mathrm{P}_{0}$. A re-probing for the GAPDH gene is shown as a loading and transfer control. Blot exposure times: $l p_{A 1}, 14 \mathrm{~d} ; G A P 43,7 \mathrm{~d} ; L N G F R, 3 \mathrm{~d} ; G A P D H, 3 \mathrm{hr} ; P_{0}$, $16 \mathrm{hr}$.

expression of the L1 adhesion molecule (Seilheimer and Schachner, 1987), both NGF and glial growth factor (neuregulin) promote SC migration in vitro (Anton et al., 1994; Mahanthappa et al., 1996), and transforming growth factor- $\beta$ stimulates expression of the gene encoding type IV collagen, a basal lamina component (Rogister et al., 1993). However, no factor has been reported to induce major changes in SC actin structure, cellsubstrate adhesion, and cell-cell contacts.

The serum phospholipid LPA, via activation of the $G_{12 / 13}$ family, is a prototypical regulator of Rho-dependent actin cytoskeletal reorganizations in several cell types (Ridley and Hall, 1992; Moolenaar, 1995; Gohla et al., 1998; Sah et al., 2000). The identification of the LPA receptor gene $l p_{A 1}$ (Hecht et al., 1996; Fukushima et al., 1998), and the demonstration of its expression by SCs (Weiner and Chun, 1999) and oligodendrocytes (Weiner et al., 1998), suggested roles for LPA signaling in the regulation of myelinating cell adhesion and morphology. The data presented here implicate $\mathrm{LP}_{\mathrm{A} 1}$-mediated LPA signaling as an endogenous regulatory system for SC morphology and adhesion.

LPA treatment of SCs led to actin rearrangements, focal ad-
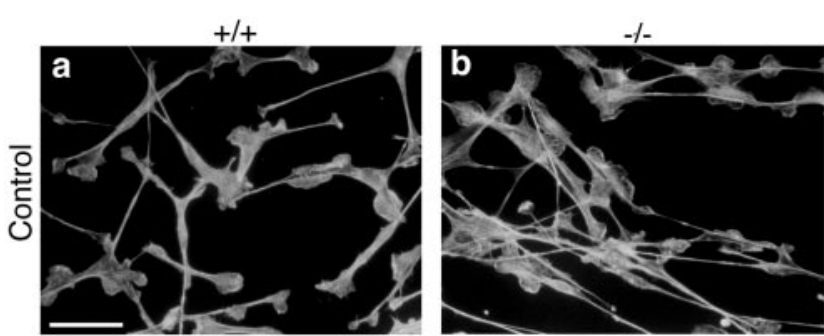

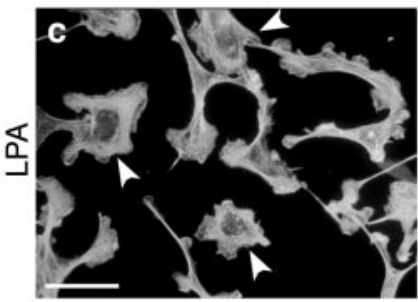

e

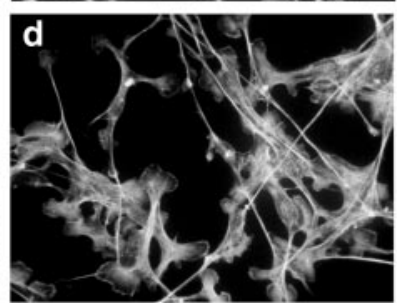

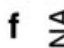

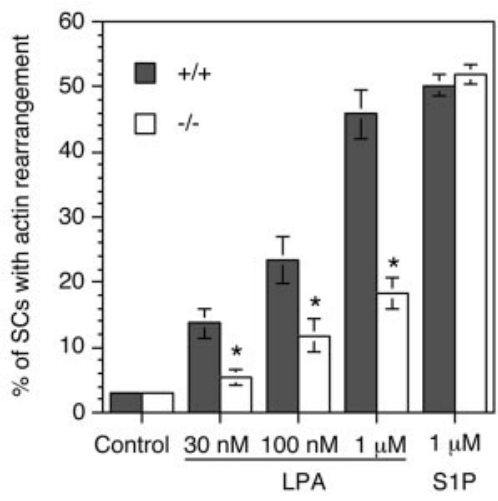

㫕 을 $\frac{\text { nerve }}{+/+-/-} \frac{\text { culture }}{+/+-/-}$

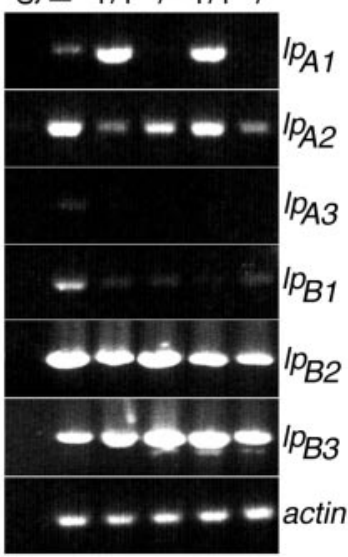

Figure 6. LPA responsiveness is greatly reduced in $l p_{A 1}{ }^{(-/-)}$Schwann cells. $a-d$, TRITC-phalloidin staining of SCs from neonatal $l p_{A 1}{ }^{(+/+)}$and $l p_{A 1}{ }^{(-/-)}$mice. $l p_{A 1}{ }^{(+/+)} \mathrm{SC}$ respond to $100 \mathrm{nM}$ LPA with the formation of actin wreath-like structures, whereas $l p_{A 1}{ }^{(-/-)}$SCs respond with only slight actin rearrangements. Scale bars, $40 \mu \mathrm{m}$. $e$, Dose-response relationship for LPA-induced actin wreath formation in $l p_{A 1}{ }^{(+/+)}$and $l p_{A 1}{ }^{(-/-)}$SCs. Values represent mean $\pm \operatorname{SEM}(n=6) . * p<0.03(-/-$ vs $+/+$ at each dose; ANOVA with Fisher's post hoc test). LPA-induced actin wreath formation is minimal in $l p_{A 1}{ }^{(-/-)} \mathrm{SCs}$, yet they respond to $\mathrm{S} 1 \mathrm{P}$ with actin rearrangements as robust as those of wild-type cells. $f$, RT-PCR detection of $l p_{A 1}, l p_{A 2}, l p_{A 3}, l p_{B 1}, l p_{B 2}$, and $l p_{B 3}$, in $l p_{A 1}{ }^{(+/+)}$and $l p_{A 1}{ }^{(-1-)}$ cultured SC and intact sciatic nerve (postnatal day 7) cDNAs. This analysis confirms the lack of expression of $l p_{A 1}$ in $l p_{A 1}{ }^{(-1-)} \mathrm{SCs}$ and nerves and suggests that the small residual LPA response may be mediated by $\mathrm{LP}_{\mathrm{A} 2}$. All primer pairs crossed intron-exon boundaries; therefore, lack of a product from PCR performed on genomic DNA ( $g D N A)$ is shown as a negative control. Lung cDNA is shown as a positive control, and PCR using actin primers is shown to indicate equivalent cDNA input.

hesion assembly, and $N$-cadherin-mediated cell clustering. Although the significance of LPA-induced focal adhesion assembly to SC biology in vivo is not yet clear, increased adhesion to ECM components, accompanied by a transition from an elongated, bipolar morphology to a flatter shape, is reminiscent of changes that occur as SCs stop migrating and begin elaborating the myelin sheath. Consistent with this are reports that laminin-integrin interactions enhance myelin formation in cultured SCs and oligodendrocytes (Fernandez-Valle et al., 1994; Buttery and ffrench-Constant, 1999). The assembly of $N$-cadherin junctions and the resulting cell clustering appear to represent a distinct response to LPA, because blocking cadherin function had no 


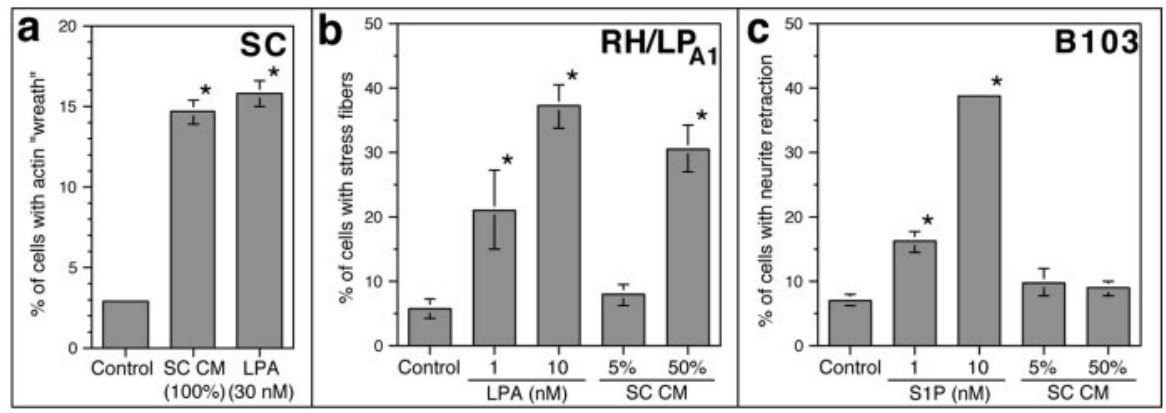

Figure 7. Schwann cell-conditioned medium contains an LPA-like activity. $a$, The effects of SC-CM on actin wreath formation in SCs. Medium conditioned by confluent SC cultures for $72 \mathrm{hr}$ induces wreath formation in fresh SC cultures with an activity equivalent to $30 \mathrm{nM}$ LPA. $b$, The effects of SC-CM on stress fiber formation in RH7777 hepatoma cells expressing $l p_{A 1}\left(\mathrm{RH} / \mathrm{LP}_{\mathrm{A} 1}\right)$. $c$, The effects of SC-CM on neurite retraction in B103 cells. $\mathrm{RH} / \mathrm{LP}_{\mathrm{A} 1}$ cells respond to SC-CM [added at 5 or $50 \%(\mathrm{v} / \mathrm{v})$ ] with stress fiber formation, whereas B103 cells do not respond to SC-CM with neurite retraction. These two sensitive and specific bioassays (Fukushima et al., 1998, 2000) suggest that the activity in SC-CM is LPA. * $p<0.01$ (vs control); values represent means $\pm \operatorname{SEM}(n=6)$.

apparent effect on actin reorganization (Fig. $4 h-k$ ). The regulation of cadherin junctions by LPA may have important consequences for SC development. Cadherin cell junctions are observed between migrating SCs and neurites in vitro (Letourneau et al., 1991) and between individual layers of the myelin sheath in vivo (Fannon et al., 1995). Furthermore, SC myelination of axons in vitro was found to be aberrant in low calcium medium (Blank et al., 1974), likely reflecting disrupted cadherin function. Initial coculture experiments have suggested that LPA also increases $N$-cadherin-containing contacts between SCs and dorsal root ganglion neurites (N. Fukushima and J. Chun, unpublished data). LPA may thus regulate cell-cell contacts in vivo not only between SCs but also between SCs and axons.

SCs isolated from $l p_{A 1}{ }^{(-/)}$mice exhibited greatly decreased LPA responsiveness. Although previous Northern blot analysis of rat SCs did not detect expression of the gene encoding $\mathrm{LP}_{\mathrm{A} 2}$, a second, related GPCR for LPA (Weiner and Chun, 1999), mouse SCs do express this gene at levels detectable by RT-PCR. The residual actin rearrangements observed in $l p_{A 1}{ }^{(-)}$SCs may thus be explained by action through $\mathrm{LP}_{\mathrm{A} 2}$, which mediates morphological responses to LPA with somewhat less efficacy than $\mathrm{LP}_{\mathrm{A} 1}$ (Ishii et al., 2000). Although SC apoptosis is significantly increased in the sciatic nerves of adult $l p_{A 1}{ }^{(-/-)}$mice (Contos et al., 2000b), myelination and sciatic nerve structure appear grossly normal (J. A. Weiner and J. Chun, unpublished data). This may reflect compensation by several signaling pathways: LPA signaling through other LPA receptors; S1P signaling, which induced similar actin reorganization in both wild-type and $l p_{A 1}{ }^{(-/-)}$ mouse SCs; and/or the action of peptide growth factors (e.g., neuregulins) on their cognate receptors.

LPA-induced cytoskeletal signaling mechanisms could conceivably contribute not only to the control of myelination (Fernandez-Valle et al., 1994, 1997; Chen et al., 2000) but also to SC survival. The major survival-promoting response to LPA in neonatal SCs is mediated through a $\mathrm{G}_{\mathrm{i}}-\mathrm{PI} 3 \mathrm{~K}-\mathrm{Akt}$ pathway (Weiner and Chun, 1999), but Rho-dependent cytoskeletal signaling mechanisms could feed into this pathway. Loss of contact with the ECM can induce a form of apoptosis called "anoikis" in several cell types, and both integrin signaling and the actin binding protein ezrin have been shown to activate the PI3K-Akt survival pathway (Frisch and Ruoslahti, 1997; Khwaja et al., 1997; King et al., 1997; Longhurst and Jennings, 1998; Gautreau et al., 1999). This is consistent with our observation that the ability of LPA to promote SC survival is enhanced when cells are grown on laminin compared with poly-L-lysine alone (J. A. Weiner and J. Chun, unpublished data). The increased apoptosis observed in the sciatic nerve of adult $l p_{A 1}{ }^{(-/-)}$mice (Contos et al., 2000b) may thus indicate that LPA signaling helps maintain the stability of SC-axon or $\mathrm{SC}-$ matrix interactions in the mature nerve. A relationship between the organization of the actin cytoskeleton and the growth and survival of SCs would not be surprising in view of the fact that loss-of-function mutations in merlin, an actinbinding protein of the ezrin-radixin-moesin family (Tsukita and Yonemura, 1999), were identified as the cause of neurofibromatosis type 2, an inherited human disorder characterized by Schwannoma formation (Rouleau et al., 1993; Scherer and Gutmann, 1996). Cultured human Schwannoma cells exhibit a markedly aberrant actin organization in culture attributable in part to abnormal Rho activation (Pelton et al., 1998).

SC survival is dependent on autocrine and/or paracrine signaling loops, in which insulin-like growth factor, neurotrophin-3, and neuregulin have been implicated (Mirsky and Jessen, 1996; Cheng et al., 1998; Meier et al., 1999). Thus, the ability of LPA to promote SC survival (Weiner and Chun, 1999) is particularly interesting in light of the present demonstration of LPA activity in SC CM. Because SCs are also dependent on axon-derived signals for survival, neurons are another potential source of endogenous LPA. Detection of LPA release by dorsal root ganglion or motor neurons in vitro has been hampered by the need for high-purity, high-cell density, extended culture times, and serum-free (i.e., exogenous LPA-free) conditions. However, we have recently identified LPA activity in medium conditioned by postmitotic cortical neurons (but not by mitotic neuroblasts) (Fukushima et al., 2000), and thus it is probable that both axons and SCs can release signaling LPA in peripheral nerves.

Collectively, the data presented here and previously (Weiner and Chun, 1999) demonstrate multiple effects of LP receptormediated LPA signaling on SC biology and suggest in vivo roles in peripheral nerve development and regeneration. The production of mice lacking multiple lysophospholipid receptor genes, as well as other methods of manipulating LPA signaling in vivo, are being pursued to test this prediction. Such studies, as well as further dissection of the signaling pathways activated by LPA in SCs, may in the future lead to novel therapies for disorders of myelination and nerve function. 


\section{REFERENCES}

Amano M, Chihara K, Kimura K, Fukata Y, Nakamura N, Matsuura Y, Kaibuchi K (1997) Formation of actin stress fibers and focal adhesions enhanced by Rho-kinase. Science 275:1308-1311.

Anton ES, Weskamp G, Reichardt LF, Matthew WD (1994) Nerve growth factor and its low-affinity receptor promote Schwann cell migration. Proc Natl Acad Sci USA 91:2795-2799.

Ausubel FM, Brent R, Kingston RE, Moore DD, Seidman JG, Smith JA, Struhl K (1994) Current protocols in molecular biology. New York: Wiley.

Blank WF, Bunge MB, Bunge RP (1974) The sensitivity of the myelin sheath, particularly the Schwann cell-axolemma junction, to lowered calcium levels in cultured sensory ganglia. Brain Res 67:503-518.

Brockes JP, Fields KL, Raff MC (1979) Studies on cultured rat Schwann cells. I. Establishment of purified populations from cultures of peripheral nerve. Brain Res 165:105-118.

Bunge MB, Bunge RP, Kleitman N, Dean AC (1989) Role of peripheral nerve extracellular matrix in Schwann cell function and in neurite regeneration. Dev Neurosci 11:348-360.

Buttery PC, ffrench-Constant C (1999) Laminin-2/integrin interactions enhance myelin membrane formation by oligodendrocytes. Mol Cell Neurosci 14:199-212.

Chen L-M, Bailey D, Fernandez-Valle C (2000) Association of $\beta 1$ integrin with focal adhesion kinase and paxillin in differentiating Schwann cells. J Neurosci 20:3776-3784.

Cheng L, Esch FS, Marchionni MA, Mudge AW (1998) Control of Schwann cell survival and proliferation: autocrine factors and neuregulins. Mol Cell Neurosci 12:141-156.

Chun J, Contos JJA, Munroe D (1999) A growing family of receptor genes for lysophosphatidic acid (LPA) and other lysophospholipids (LPs). Cell Biochem Biophys 30:213-242.

Cifuentez-Diaz C, Nicolet M, Goudou D, Rieger F, Mege RM (1994) $\mathrm{N}$-cadherin expression in developing, adult, and denervated chicken neuromuscular system: accumulations at both the neuromuscular junction and the node of Ranvier. Development 120:1-11.

Contos JJ, Chun J (1998) Complete cDNA sequence, genomic structure, and chromosomal localization of the LPA receptor gene, lpA1/vzg-1/ Gpcr26. Genomics 51:364-378.

Contos JJA, Chun J (2000) Genomic characterization of the lysophosphatidic acid receptor gene, $\operatorname{lp} \mathrm{p}_{\mathrm{A} 2} / \mathrm{Edg} 4$, and identification of a frameshift mutation in a previously characterized cDNA. Genomics 64:155-169.

Contos JJA, Ishii I, Chun J (2000a) Lysophosphatidic acid receptors. Mol Pharmacol 58:1188-1196.

Contos JJA, Fukushima N, Weiner JA, Kaushal D, Chun J (2000b) Requirement for the $l p_{\mathrm{A} 1}$ lysophosphatidic acid receptor gene in normal suckling behavior. Proc Natl Acad Sci USA 97:13384-13389.

Fannon AM, Sherman DL, Ilyina-Gragerova G, Brophy PJ, Friedrich Jr VL, Colman D (1995) Novel E-cadherin-mediated adhesion in peripheral nerve: Schwann cell architecture is stabilized by autotypic adherens junctions. J Cell Biol 129:189-202.

Fernandez-Valle C, Gwynn L, Wood PM, Carbonetto S, Bunge MB (1994) Anti-beta1 integrin antibody inhibits Schwann cell myelination. J Neurobiol 25:1207-1226.

Fernandez-Valle C, Gorman D, Gomez AM, Bunge MB (1997) Actin plays a role in both changes in cell shape and gene expression associated with Schwann cell myelination. J Neurosci 17:241-250.

Fernandez-Valle C, Wood PM, Bunge MB (1998) Localization of focal adhesion kinase in differentiating Schwann cell/neuron cultures. Microsc Res Tech 41:416-430.

Fort P, Marty L, Piechaczyk M, Sabrouty SE, Dani C, Jeanteur P, Blanchard JM (1985) Various rat adult tissues express only one major mRNA species from the glyceraldehyde 3-phosphate dehydrogenase multigenic family. Nucleic Acids Res 13:1431-1442.

Frisch SM, Ruoslahti E (1997) Integrins and anoikis. Curr Opin Cell Biol 9:701-706.

Fu SY, Gordon T (1997) The cellular and molecular basis of peripheral nerve regeneration. Mol Neurobiol 14:67-116.

Fukushima N, Kimura Y, Chun J (1998) A single receptor encoded by vzg-1/lpA1/edg-2 couples to G-proteins and mediates multiple cellular responses to lysophosphatidic acid (LPA). Proc Natl Acad Sci USA 95:6151-6156.

Fukushima N, Weiner JA, Chun J (2000) Lysophosphatidic acid (LPA) is a novel extracellular regulator of cortical neuroblast morphology. Dev Biol 228:6-18.

Fukushima N, Ishii I, Contos JJA, Weiner JA, Chun J (2001) Lysophospholipid receptors. Annu Rev Pharmacol Toxicol 41:507-534.

Gautreau A, Poullet P, Louvard D, Arpin M (1999) Ezrin, a plasma membrane-microfilament linker, signals cell survival through the phosphatidylinositol 3-kinase/Akt pathway. Proc Natl Acad Sci USA 96:7300-7305.

Gohla A, Harhammer R, Schultz G (1998) The G-protein G13 but not G12 mediates signaling from lysophosphatidic acid receptor via epidermal growth factor receptor to Rho. J Biol Chem 273:4653-4659.
Hecht JH, Weiner JA, Post SR, Chun J (1996) Ventricular zone gene-1 (vzg-1) encodes a lysophosphatidic acid receptor expressed in neurogenic regions of the developing cerebral cortex. J Cell Biol 135:1071-1083.

Ishii I, Contos JJA, Fukushima N, Chun J (2000) Functional comparisons of the lysophosphatidic acid receptors, LPA1/VZG-1/EDG-2, LPA2/EDG-4, and LPA3/EDG-7 in neuronal cell lines using a retrovirus expression system. Mol Pharmacol 58:895-902.

Jalink K, Eichholtz T, Postma FR, van Corven EJ, Moolenaar WH (1993) Lysophosphatidic acid induces neuronal shape changes via a novel, receptor-mediated signaling pathway: similarity to thrombin action. Cell Growth Differ 4:247-255.

Jalink K, van Corven EJ, Hengeveld T, Morii N, Narumiya S, Moolenaar WH (1994) Inhibition of lysophosphatidate- and thrombin-induced neurite retraction and neuronal cell rounding by ADP ribosylation of the small GTP-binding protein Rho. J Cell Biol 126:801-810.

Jessen KR, Brennan A, Morgan L, Mirsky R, Kent A, Hashimoto Y, Gavrilovic J (1994) The Schwann cell precursor and its fate: a study of cell death and differentiation during gliogenesis in rat embryonic nerves. Neuron 12:509-527.

Khwaja A, Rodriguez-Viciana P, Wennstrom S, Warne PH, Downward J (1997) Matrix adhesion and Ras transformation both activate a phosphoinositide 3-OH kinase and protein kinase B/Akt cellular survival pathway. EMBO J 16:2783-2793.

King WG, Mattaliano MD, Chan TO, Tsichlis PN, Brugge JS (1997) Phosphatidylinositol 3-kinase is required for integrin-stimulated AKT and $\mathrm{raf}-1 / \mathrm{mitogen}-\mathrm{activated}$ protein kinase pathway activation. Mol Cell Biol 17:4406-4418.

Lee M-J, Van Brocklyn JR, Thangada S, Liu CH, Hand AR, Menzeleev R, Spiegel S, Hla T (1998) Sphingosine-1-phosphate as a ligand for the G protein-coupled receptor EDG-1. Science 279:1552-1555.

Lemke G (1993) The molecular genetics of myelination: an update. Glia $7: 263-271$

Lemke G, Axel R (1985) Isolation and sequence of a cDNA encoding the major structural protein of peripheral myelin. Cell 40:501-508

Letourneau PC, Shattuck TA, Roche FK, Takeichi M, Lemmon V (1990) Nerve growth cone migration onto Schwann cells involves the calcium-dependent adhesion molecule, $N$-cadherin. Dev Biol 138:430-442.

Letourneau PC, Roche FK, Shattuck TA, Lemmon V, Takeichi M (1991) Interactions of Schwann cells with neurites and with other Schwann cells involve the calcium-dependent adhesion molecule, $N$-cadherin. J Neurobiol 22:707-720.

Longhurst CM, Jennings LK (1998) Integrin-mediated signal transduction. Cell Mol Life Sci 54:514-526.

Mahanthappa NK, Anton ES, Matthew WD (1996) Glial growth factor 2 , a soluble neuregulin, directly increases Schwann cell motility and indirectly promotes neurite outgrowth. J Neurosci 16:4673-4683.

Meier C, Parmantier E, Brennan A, Mirsky R, Jessen KR (1999) Developing Schwann cells acquire the ability to survive without axons by establishing an autocrine circuit involving insulin-like growth factor, neurotrophin-3, and platelet-derived growth factor-BB. J Neurosci 19: 3847-3859.

Milner R, Wilby M, Nishimura S, Boylen K, Edwards G, Fawcett J, Streuli C, Pytela R, ffrench-Constant C (1997) Division of labor of Schwann cell integrins during migration on peripheral nerve extracellular matrix ligands. Dev Biol 185:215-228.

Mirsky R, Jessen KR (1996) Schwann cell development, differentiation, and myelination. Curr Opin Neurobiol 6:89-96.

Moolenaar WH (1995) Lysophosphatidic acid signalling. Curr Opin Cell Biol 7:203-210.

Moolenaar WH, Kranenburg O, Postma FR, Zondag GCM (1997) Lysophosphatidic acid: G-protein signalling and cellular responses. Curr Opin Cell Biol 9:168-173.

Pelton PD, Sherman LS, Rizvi TA, Marchionni MA, Wood P, Friedman RA, Ratner N (1998) Ruffling membrane, stress fiber, cell spreading and proliferation abnormalities in human Schwannoma cells. Oncogene 17:2195-2209.

Postma FR, Jalink K, Hengeveld T, Moolenaar WH (1996) Sphingosine1-phosphate rapidly induces Rho-dependent neurite retraction: action through a specific cell surface receptor. EMBO J 15:2388-2392.

Radeke MJ, Misko TP, Hsu C, Herzenberg LA, Shooter EM (1987) Gene transfer and molecular cloning of the rat nerve growth factor receptor. Nature 325:593-597.

Ramon y Cajal S (1928) Degeneration and regeneration of the nervous system. New York: Oxford UP.

Ridley AJ, Hall A (1992) The small GTP-binding protein Rho regulates the assembly of focal adhesions and actin stress fibers in response to growth factors. Cell 70:389-399.

Rogister B, Delree P, Leprince P, Martin D, Sadzot C, Malgrange B Munaut C, Rigo JM, Lefebvre PP, Octave J-N, Schoenen J, Moonen G (1993) Transforming growth factor beta as a neuronoglial signal during peripheral nervous system response to injury. J Neurosci Res $34: 32-43$

Rouleau GA, Merel P, Lutchman M, Sanson M, Zucman J, Marineau C, 
Hoang-Xuan K, Demczuk M, Desmaze C, Plougastel B, Pulst SM, Lenoir G, Bijisma E, Fashold R, Dumanski J, de Jong P, Parry D, Eldrige R, Aurias A, Delattre O, Thomas G (1993) Alteration in a new gene encoding a putative membrane-organizing protein causes neuro-fibromatosis type 2. Nature 363:515-521.

Sah VP, Seasholtz TM, Sagi SA, Brown JH (2000) The role of Rho in G protein-coupled receptor signal transduction. Annu Rev Pharmacol Toxicol 40:459-489.

Scherer SS (1997) The biology and pathobiology of Schwann cells. Curr Opin Neurol 10:386-397.

Scherer SS, Gutmann DH (1996) Expression of the neurofibromatosis 2 tumor suppressor gene product, merlin, in Schwann cells. J Neurosci Res 46:595-605.

Scherer SS, Wang DY, Kuhn R, Lemke G, Wrabetz L, Kamholz J (1994) Axons regulate Schwann cell expression of the POU transcription factor SCIP. J Neurosci 14:1930-1942.

Seilheimer B, Schachner M (1987) Regulation of neural cell adhesion molecule expression on cultured mouse Schwann cells by nerve growth factor. EMBO J 6:1611-1616.

Shibuya Y, Mizoguchi A, Takeichi M, Shimada K, Ide C (1995) Localization of $N$-cadherin in the normal and regenerating nerve fibers of the chicken peripheral nervous system. Neuroscience 67:253-261.

Tsukita S, Yonemura S (1999) Cortical actin organization: lessons from ERM (Ezrin/Radixin/Moesin) proteins. J Biol Chem 274: 34507-34510.

Uehata M, Ishizaki $\mathrm{T}$, Satoh $\mathrm{H}$, Ono $\mathrm{T}$, Kawahara $\mathrm{T}$, Morishita $\mathrm{T}$, Tamakawa H, Yamagami K, Inui J, Maekawa M, Narumiya S (1997) Calcium sensitization of smooth muscle mediated by a Rho-associated protein kinase in hypertension. Nature 389:990-997.

van Brocklyn JR, Tu Z, Edsall LC, Schmidt RR, Spiegel S (1999) Sphingosine 1-phosphate-induced cell rounding and neurite retraction are mediated by the $\mathrm{G}$ protein-coupled receptor H218. J Biol Chem 274:4626-4632.

Weiner JA, Chun J (1999) Schwann cell survival mediated by the signaling phospholipid lysophosphatidic acid. Proc Natl Acad Sci USA 96:5233-5238.

Weiner JA, Hecht JH, Chun J (1998) Lysophosphatidic acid receptor gene vzg-1/lp $\mathrm{p}_{1} / \mathrm{edg}-2$ is expressed by mature oligodendrocytes during myelination in the postnatal murine brain. J Comp Neurol 398:587-598.

Yap AS, Brieher WM, Gumbiner M (1997) Molecular and functional analysis of cadherin-based adherens junctions. Annu Rev Cell Dev Biol 13:119-146.

Zhang G, Contos JJA, Weiner JA, Fukushima N, Chun J (1999) Comparative analysis of three murine G-protein coupled receptors activated by sphingosine-1-phosphate. Gene 227:89-99.

Zorick TS, Lemke G (1996) Schwann cell differentiation. Curr Opin Cell Biol 8:870-876. 